\title{
IMPLICATIONS OF IFRS ADOPTION ON EARNINGS QUALITY, EMPIRICAL CASE FOR ROMANIAN ENVIRONMENT
}

\author{
Burca Valentin ${ }^{l}$ \\ Mates Dorel ${ }^{2}$
}

\begin{abstract}
Globalization process has determined visible changes on international accounting regulation, describing a predictive direction of financial reporting development towards IFRS adoption. IFRS is perceived, within the international accounting convergence project, as the unique financial reporting language which lead to more comparable financial information, a higher transparency and an improvement of value relevance. Romanian IFRS adoption case is a specific as the main reasons determining IFRS adoption were mainly defined by the pressure of the international financial institutions and the political factor, not by market-driven motivations. Mandatory IFRS adoption hasn't generated the expected economic benefits as the incentives for a real adoption did not cover the high implementation costs. Our study is aimed to check earnings quality ex-ante and ex-post IFRS adoption. Overall, there is evidence that earnings quality increase, but not in a spectacular proportion as the differences between local GAAP and IFRS regarding the main controversial accounting topics are significantly reduced along the last ten year.
\end{abstract}

Key words: IFRS, accruals, earnings management, regression.

JEL: M40, M41, G33.

\section{Introduction}

Earnings quality subject is still recent as there is a vivid debate around motivations, determinants and consequences of earnings management. Earnings management practices represent a reality we can't deny because of the gaps between accounting system and the economic system dynamics. A significant part is represented by the practices of manipulating earnings through accounting choice which give managers the opportunity to use multiple accounting choices for treatments. The freedom assured by the overt and covert options allowed by IFRS is clearly affecting the quality of the financial information, leading to moral hazard and adverse selection that hamper efficient investment (Biddle et. al., 2009).

Shortly, financial reporting quality can be defined as the extent to which financial statements provide true and fair information about the financial position and economic performance of the reporting entity. Beyond general accounting principles, the central role of the qualitative characteristics, on this direction, is confirmed by Nobes \& Stadler (2014) study, which reveal that managements' accounting decisions are regularly referred to qualitative characteristics such as comparability, faithful representation or understandability. This study is essential, as there are outlined many times contradictory situations between accounting principles and qualitative characteristics (Gunther et. al., 2014).

We subscribe to prof. Ristea \& Dumitru (2012) definition, who considered the liberty on accounting choice will actually represent a balance between value relevance and credibility. But this would not be enough, as disclosed financial information can be affected be uncertainty, or has

\footnotetext{
${ }^{1}$ PhD Student West University of Timisoara

${ }^{2} \mathrm{PhD}$ Professor West University of Timisoara
} 
to be used on a time series analysis, cases which require additional qualitative characteristics. It is welcome IASB position which has made a clear separation between the qualitative characteristics, splitting them into fundamental characteristics (relevance and faithful representation) and enhancing characteristics (comparability, verifiability, timeliness and understandability). This way, the main focus must be on the fundamental characteristics as if they are not valid, the financial information will surely not be useful even if it would be comparable of verifiable.

Current debate is concentrated around the discussion regarding the interconnection between all these characteristics, in order to obtain accurate financial information. Just that faithful representation becomes utopic if we consider the financial information has to be complete, neutral and free of error, as we all realize that the problem of measurement in accounting is facing the need of using estimates.

Unfortunately, the solution of international accounting convergence seem to be unable to find solutions to international accounting diversity, considering the complexity of each economic system, or even individual entity business model. IASB solution of allowing multiple choices in setting accounting policies on different treatments, accepted under political pressure, is the base for earnings management through accounting choice.

Our study is designed to reveal some insights regarding earnings quality and financial reporting quality in the Romanian environment around the IFRS transition period. The efforts the local standard-setter have made in order to reduce the differences between IFRS and local GAAP are visible. But we must not forget that main players that determined IFRS adoption in our country case are the international financial institutions, as we had an underdeveloped capital market and the main capital provider is the banking system.

By issuing OMF 907/2005 (amended by OMPF 2001/2006 and 1121/2006), public companies are mandated to prepare consolidated financial statements under IFRS standards as endorsed by the EU. In parallel, other companies may opt for voluntary adoption of IFRS, for information purposes, without being exempt from having to draw consolidated financial statements according to OMPF 1752/2005. Next step was the adoption of IFRS in the statutory financial statements of listed companies, regulated by OMPF 1286/2012. Actually, IFRS is mandatory for statutory and consolidated financial statement for financial institutions and listed companies.

The mandatory adoption has revealed question marks regarding the real implications on the entities. All these entities were forced to implement IFRS even if the financial information demand until recently was shaped by the conservative system of banks. Moreover, the incompatibilities between traditional Romanian accounting model and IASB accounting model are significant and refer to multiple dimensions of reform, such as deregulation process, capital market development, development of accounting profession, replacement of general accounting plan with the financial reporting conceptual framework, the reconsideration of criteria for accounting recognition and classification, and the most important, the use of accounting judgment that has to become central in the rationale of financial reporting process (Feleaga, 1999). This consideration is important because a superficial IFRS implementation does not just generate the expected economic benefits, but also leads to negative externalities.

Even is the literature along the last decade has encountered a positive evolution of local accounting regulation towards IFRS requirements, the harmonization level is still relatively low, leading to a dual accounting reality in Romanian economic environment. Moreover, it seems that cultural factor in this case persist, Romanian accountants preferring statutory control, uniformity, conservatism and transparency (Olimid \& Calu, 2006). On these circumstances, it is more challenging to view IFRS impact on accounting figures, as IFRS philosophy is a principle-based doctrine, contrary to the cultural Romanian accounting traditional model considered as rules-based accounting. Additionally, the strong connection between fiscal rules and accounting treatment will 
raise further questions related to the value relevance of the financial information, as it could be sacrificed in change of the fiscal savings that entities can obtain from the state. All these would mean an opportunistic use of accounting choice regarding assets and liabilities recognition and classification, which would lead to lower gross profit. Also, there is the risk of reporting higher debt ratio, under the presumption of a relatively high level of accounting conservatism, which could increase the cost of capital.

If Romanian economic environment does not find answers in short time to all these inconsistencies, managers will be able to avoid financial reporting strategies meant to assure a true and fair presentation of earnings.

The study will refer to a sample of listed companies on BSE market, reflecting all domains of activity. For this we will use some of the most well-known econometric models depicting causal relation between accruals and cash flow value. Our research will limit to most cited models, including here Jones (1991), Kasznik (1999), Dechow (2002), Francis et. al. (2005), Kothari \& Jones, and Ball \& Shivakumar (2006) models.

The study will analyze the trend of the $\mathrm{R}^{2}$ specific to the regression models built on the base of a sample of BSE listed companies and will emphasize the importance of discretionary accruals in earnings structure, in order to show qualitative characteristics of financial information like value relevance, or predictability.

\section{Literature review}

There is an endless discussion in the literature regarding earnings management, the motivations that stay behind them, or the determinants and consequences corresponding to any form of accounting manipulation (Dechow et. al., 2010). This review seem to highlight a lack of a clear definition of what earnings management means, drawing several motivations behind the practices of earnings management and accounting manipulation. It also try to make an in-depth analysis of the impact of earnings management on decision making, by analyzing earnings and accruals quality, in order to isolate the discretionary component reflecting bad accounting practices or simple transitory transactions.

It is clear that all these practices aim to alter, or distort a company's true financial position and economic performance in order to mislead the users of financial information on the decisionmaking process. What differ among the existing definitions is the distinction between real manipulation (timing of transactions) and artificial manipulation (timing and form of presentation).

The interest for accountings manipulation, as a considerable part of earnings management practices, is visible on numerous areas such as firm valuation, debt contracting, managers' accountability, or executive compensation contracts (Dichev et al., 2013).

Financial information quality is essential as it impact directly the investment decision, and financing decision as well. Managers tend to manipulate earnings in order to improve the EPS value on short term. For instance, Graham et al. (2005) reveal in on study that, for financial managers, earnings management is more important than maximizing shareholder value, because they prefer to reject projects which have positive NPV, but which affect earnings on short term negatively.

On the other side, we remind prof. Chris Nobes's position that the financing system is the main reason for accounting diversity on the IFRS era (Nobes, 2011). This study results can be corroborated with Ball et. al. (2014) study who emphasize the trend the financial institution draw on using less debt accounting-based covenants, because of the effect of using the fair value basis. This lead us to the conclusion that strong capital markets will favor the use of fair value accounting, but will sacrifice the usefulness of financial information from banks perspective.

There is strong evidence that CEOs are employed based on their ability to manage earnings in order to increase share prices (Francis et. al., 2008), reduce tax burden (Armstrong et. al., 2012), 
or just reduce the cost of capital (Demirkan et. al., 2012). This proves the importance of the quality of used accounting judgments and estimates along the financial reporting supply chain, as there is major flexibility for managers in designing various creative techniques in order to better control the errors in earnings estimation and smoothing.

Currently, it is confirmed a clear direction towards an IFRS worldwide adoption. More than 100 jurisdictions have already chosen to mandate the use of IFRS on preparing the financial statements. The quality of IFRSs is confirmed by numerous empirical studies, revealing a significant increase on the comparability and value relevance of the disclosed financial information, more accurate forecasts, or slight conditional conservatism reduction (Chen et. al., 2010; Barth et. al., 2012; Horton et. al., 2013; Andre et. al., 2013).

Even though, the evidence shows persistence of accounting differences along the IFRS adoption process, because of various technical reasons, based on financing strategy, political, or cultural diversity across the jurisdictions (Nobes, 2011). This way, they have been conducted studies revealing that IFRS adoption will lead to better financial information, but under a conditional context. That is why they are studies that underline the real importance of existing incentives stimulating managers' financial reporting strategies, who have realized that capital market can penalize them in case of lower transparency and poor financial information quality (Christensen et. al., 2007). Moreover, there is drawn the fundamental role of the changes in enforcement in order to assure a proper implementation and use of IFRS on a medium and long term (Barth \& Israeli, 2013).

Most of negative perception translated in reluctance towards IFRS adoption is mainly determined by the lack of prior studies discussing IFRS effects and challenges on the local economic environment, and by the insignificant reporting incentives level determined by an emerging capital market as BSE (Bucharest Stock Exchange) still is. On this context it is essential that accounting standard-setters and local enforcement institutions to pay attention to the role of reporting incentives (especially the market-driven ones), because the quality of the accounting standards does not necessary traduce into qualitative financial reporting (Christensen et. al., 2007; Jayaraman \& Verdi, 2014).

There is still place for improvement, as even IASB admit through its continuous improvement strategy, aimed to review the existing accounting standards and issue new ones (Burca, 2014). This way IASB has achieved to gain a global legitimacy and support from regional and local standard-setters, and national enforcement organizations. But, the results of prior studies must be used cautiously because of the increasing flexibility of the revised and the new IFRSs, as they permit more options in areas of earnings smoothing, especially in the case of mandatory IFRS adopters whose accounting policies depend on market and institutional incentives (Capkun et. al., 2012).

\section{IFRS adoption and impact on earnings quality, Romanian case}

Decision of IFRS adoption in Romanian case is relatively recent, as a condition of joining the EU community. According to IAS Regulation, every EU jurisdiction had to mandate reporting entities to use IFRS for consolidated financial statements, and permitted to those who wanted the use of IFRS on the statutory financial statements as well. Romania has chosen to adopt IFRS gradually on both, the consolidated and statutory financial statements as well. Now the question remaining to find an answer is around the implications on investment and financing decision at the reporting entity level.

Ionascu et. al. (2014) achieved to make a global overview of the accounting literature, realizing a general picture of the historical evolution, with its cultural connections, and an overview 
of the costs and benefits of IFRS use confirmed in literature. The study reveal the cost considerations that made most of the firms reluctant towards an effective IFRS adoption, as they are claimed considerable costs for personal training, multiple reporting requirements, or tax burden change. They highlight the benefits of IFRS as well, dividing them into two main categories, the perceived benefits (increase in transparency, facilitate external capital access, improve financial information comparability by reducing forecasts errors, using fair value and extending the financial disclosure requirements) and the empirically documented benefits (increase in disclosure requirements).

As concerns the quality of reporting earnings, there is still little interest, because of missing data, or the short time frame passing from first IFRS adoption. We consider a significant contribution to the literature has been realized through the following empirical studies, concerning the the evolution of the quality of disclosed financial information: Mihai (2008), Filip \& Raffournier (2010), Matis \& Sucala (2010), Ionascu (2011), Takacs (2012), Burca \& Nagy (2013), Brad et. al. (2014), Pascan (2014).

Starting from a sample of 235 observations covering the period 2000-2004, Mihai (2008) analyze the quality of financial information in terms of accounting conservatism, in the context of local accounting regulation which was harmonized with existing IAS at that time. Using Basu model (1997), the study reveal no increase in the quality of accounting information, in terms of timely loss recognition. This result should have been predictable as the Romanian accounting model is still dominated by the cultural factor promoting high level of prudence in financial reporting. Additionally, Mihai outline the central role of the institutional factors and reporting incentives that should be considered on drawing the strategy of harmonizing local accounting regulation with IAS.

Filip \& Raffournier (2010) have conducted a study on the local capital market, starting the analysis from a sample of 48 listed companies, considering financial exercises from period 19982004. The study outlines, under the EMH (efficient market hypothesis) constraint, a slight increase in value relevance for disclosed financial information generated by the Romanian accounting reform, making reference to regulation OMFP 94/2001. Moreover, the same study reject the hypothesis stating that the prices lead the earnings, which would lead us to the conclusion that there is no evidence towards earnings management through targets.

Indeed, these results were expected as regulation OMFP 94/2001 was a pure expression of IAS regulation, as a result of collaboration between Romanian accounting regulators and ICAS, within Romanian Accountancy Development Program (Albu, 2012). The differences between the French-based accounting traditional model and the revised anglo-saxon based accounting model were significant. Even though, the impact on accounting quality was just moderate, and with high variations within the sample, this reality could have been explained again by the cultural factor.

First attempt on studying the relevance of accruals models in the Romanian economic environment is made by Matis et. al. (2010). Their study validates Jones (1991) model, rejecting the model validity in case of Dechow (2002) and Kasznik model (1999). They focused their research on the consolidated accounts, as IFRS was mandated only for these financial statements from 2007, considering a sample of BSE listed companies for which they gathered firm observations for 2007 and 2008. The explanation could reside from the poor correlation between the accruals level and the variation of the cash flow from operations. This would mean that Romanian accountants make use in excess of the accrual accounting tools, like provisions, use of historical cost, and the list can continue, in order to reduce the profit base and maximize the level of fiscal economies.

Ionascu (2011) has realized a study testing the accuracy of the provisional figures disclosed under the period of 2008-2010 by the companies listed on the local capital market. The study confirm a positive correlation of the accuracy of the provisional accounting figures with the conservative component decision of managers, who are reluctant on disclosing estimated figures 
leading to potential litigation costs. Additionally, the study reveal a positive effect of using the fair value basis on accounting measurement as well. But this correlation is conditioned by adopting a set of high-quality corporate governance mechanisms, which can lead to an increase in financial transparency for reporting entities.

Takacs (2012) has made a study concerning the value relevance of accounting information, using similar approach to Filip \& Raffournier (2010). Starting from sample observations depicting period 2005-2010, with reference to consolidated financial statements, the result describe a moderate increase in value relevance of financial information. The study reveal as well the impact of the transitory earnings generated by transition to IFRS, decision considered as a condition for Romania to join EU community. Mainly, the study describes a significant increase on short term of value relevance for disclosed financial information. Further, the period 2007-2010 is described with a slight decrease on the value relevance of the disclosed financial information, which can be explained by the more flexible accounting model promoted by IASB on financial reporting, and consequently a wider range on accounting choice leading to more visible earnings smoothing.

The period analyzed is characterized by deep changes in accounting regulation, making reference especially to the regulation OMFP 1752/2005, consider by most of practitioners a step back towards harmonization of accounting local regulation with IFRS. Indeed, this regulation is more oriented on harmonizing the local accounting practices with the European Directives. But this step is an obligation as Romania has joined EU community, meaning the proper solution in the direction of harmonizing Romanian accounting regulation with IFRS would be that EU community to consider the perspective of harmonizing the EU directives with IFRS as they are numerous differences between the two accounting models.

Brad et. al. (2014) have conducted a study analyzing the impact of using IFRS on preparing the individual financial statements, as beginning with 2012 financial year, according with OMPF $1286 / 2012$, all listed companies were obliged to use IFRS on individual financial statements as well. The study analyze the variation of net income and cash flow for accounting figures describing financial year 2011 (reported according to OMFP 3055/2009) and 2012 (reported according to IFRS), finding no significant differences, just a slight improvement on reducing earnings smoothing effects. But, there is evidence that managers proceed to real activities earnings management, as the variability of cash flows on this transition process is really high compared to the variability of the net income.

Burca \& Nagy (2013) have analyzed the correlation between accruals and cash flow from operations, as this metric is well-known on depicting a proper view of increasing the value relevance of financial information. The study reveal a significant improvement in terms of correlation between accruals and cash flows generated by operations once IFRS are used on preparing the individual financial statements. The same study reveal a positive relation between CFO (cash flow from operations) and variation on accruals generated by transition from local accounting regulation to IFRS, and a stronger causal relation between ROA and accounting figures disclosed in 2011 (reported according to local accounting) and 2012 (reported according to IFRS) financial statements. The impact of accounts classification in the transition process is another reality revealed by the study, as in case of accounts reported by firms using indirect method for cash flow calculation, the variation is higher than in case of firms using direct method. Even though, these changes are low in absolute value, just more significant in terms of $\mathrm{R}$ square describing econometric models used.

Important are also the results obtained by Pascan (2014), whose study analyze the impact of IFRS adoption on the value relevance of financial information, in terms of book value equity versus share price and net income versus share price. In both cases there is reported a positive relation between share prices and accounting-based covenants, but with a higher increase in $\mathrm{R}$ square in case the model describing the relation between share price and book value of equity. The 
study reveal also, a higher slight increase of net income value relevance in case of local listed companies compared to the foreign ones. This can lead us to the conclusion that, even if the accounting figures are more connected to market prices, the interest for earnings smoothing is still vivid within managers, especially in case of foreign reported listed entities.

\section{Methodological research}

Earnings quality means we have to look for consistency of reporting choices over time, long-term estimates avoidance, earnings persistence based on a real economic growth, a strong correlation between earnings and future cash flows, a less volatile behavior of earnings than cash flow variations, or simply the achievement of a benchmarked level of earnings (Dechow et. al., 2010; Dichev et. al., 2013). Thus, all the metrics used on measuring earnings quality use as fundamental references the measures of cash accounting (such as $\mathrm{CFO}$ - cash flow from operating activities, FCF- free cash flow, CFF-retained earnings) and the financial performance metrics of the accruals accounting model (such as Sales, EBITDA- earnings before interests, taxes and depreciation, EBIT- earnings before interests and taxes, EBT- earnings before taxes, NI- net income). If fact, by definition, earnings consist of a component of cash accounting and another component of accruals accounting (Earnings $=$ Cash + Accruals). The level of financial performance aggregates differ based on the objectives of the analysis proceeded.

Overall, earnings are relevant as long as they are more persistent and less volatile, and strongly associated with cash flow realizations and contemporaneous stock price performance or market value (Dechow \&Schrand, 2004, p. 20).

Table 1

\section{Popular academic model of earnings management detection}

\begin{tabular}{|c|c|}
\hline \multicolumn{2}{|l|}{$D$ Jones model (1991) } \\
\hline $\begin{array}{c}A C C R=\alpha_{0}+\alpha_{1} \cdot \Delta R e v+\alpha_{2} \cdot P P E \\
+\varepsilon\end{array}$ & $\begin{array}{l}A C C R-\text { total accrual, measured by the difference of EBIT } \\
\text { and CFO; } \triangle R e v \text { - change in revenue; } P P E \text { - gross value of } \\
\text { property, plant and equipment; }\end{array}$ \\
\hline \multicolumn{2}{|l|}{$>$ Dechow model (1995) } \\
\hline $\begin{array}{l}\text { ACCR }=\alpha_{0}+\alpha_{1} \cdot(\Delta \operatorname{Rev}- \\
\Delta \operatorname{Rec})+\alpha_{2} \cdot P P E+\varepsilon\end{array}$ & $\begin{array}{l}A C C R-\text { total accrual; } \triangle R e v \text { - change in revenue; } \triangle R e c- \\
\text { change in net account receivables; } P P E \text { - gross value of } \\
\text { property, plant and equipment; }\end{array}$ \\
\hline \multicolumn{2}{|l|}{$>$ Kasznik model (1999) } \\
\hline $\begin{array}{l}A C C R=\alpha_{0}+\alpha_{1} \cdot(\Delta \operatorname{Rev}- \\
\Delta R e c)+\alpha_{2} \cdot P P E+\alpha_{3} \cdot \Delta C F O+\varepsilon\end{array}$ & $\begin{array}{l}A C C R-\text { total accrual; } \triangle R e v \text { - change in revenue; } \triangle R e c- \\
\text { change in net account receivables; } P P E \text { - gross value of } \\
\text { property, plant and equipment; } \triangle C F O \text { - change in operating } \\
\text { cash flow; }\end{array}$ \\
\hline \multicolumn{2}{|l|}{$>$ Dechow model (2002) } \\
\hline $\begin{array}{l}\Delta W C_{t}=\alpha_{0}+\alpha_{1} \cdot C F_{t-1}+\alpha_{2} . \\
C F_{t}+\alpha_{3} \cdot C F_{t+1}+\varepsilon\end{array}$ & $\Delta W C_{t}-$ total accrual; $C F_{t^{-}}$cash flow for year $t$ \\
\hline \multicolumn{2}{|l|}{$>$ Francis et. al. model (2005) } \\
\hline $\begin{array}{l}T C A_{t}=\alpha_{0}+\alpha_{1} \cdot C F O_{t}+\alpha_{2} \cdot \\
C F O_{t+1}+\alpha_{3} \cdot C F_{t+1}+\alpha_{4} \cdot \Delta R e v+ \\
\alpha_{5} \cdot P P E+\varepsilon_{t} \\
\sigma\left(\varepsilon_{t}\right)=\alpha_{0}+\alpha_{1} \cdot \text { Size }+\alpha_{2} . \\
\sigma(C F O)+\alpha_{3} \cdot \sigma(\text { Rev })+\alpha_{4} \cdot \\
\text { log(OperCycle })+\alpha_{5} \cdot \text { NegEarn }_{t}+ \\
v_{t}\end{array}$ & $\begin{array}{l}T C A_{t^{-}} \text {total current accruals; } C F O-\text { cash operating } \\
\text { activities; } \triangle R e v \text { - change in revenue; } ; P P E \text { - gross value of } \\
\text { property, plant and equipment; OperCycle- length of } \\
\text { operating cycle; NegEarn- incidence of negative earnings } \\
\text { realizations; } v_{t} \text { - discretionary component of accruals; }\end{array}$ \\
\hline
\end{tabular}




\begin{tabular}{|c|c|}
\hline \multicolumn{2}{|l|}{$>$ Kothary \& Jones model (2005) } \\
\hline $\begin{array}{l}A C C R=\alpha_{0}+\alpha_{1} \cdot \Delta R e v+\alpha_{2} \\
P P E+\alpha_{3} \cdot R O A_{t}+\varepsilon\end{array}$ & $\begin{array}{l}A C C R-\text { total accrual; } \triangle R e v-\text { change in revenue; } P P E- \\
\text { gross value of property, plant and equipment; } R O A_{t}-\text { return } \\
\text { on assets; }\end{array}$ \\
\hline \multicolumn{2}{|c|}{$>$ Kothary \& Jones modified model (2005) } \\
\hline $\begin{array}{l}A C C R=\alpha_{0}+\alpha_{1} \cdot(\Delta R e v- \\
\Delta R e c)+\alpha_{2} \cdot P P E+\alpha_{3} \cdot R O A_{t}+\varepsilon\end{array}$ & $\begin{array}{l}A C C R-\text { total accrual; } \triangle R e v \text { - change in revenue; } \triangle R e c- \\
\text { change in net account receivables; } P P E \text { - gross value of } \\
\text { property, plant and equipment; } R O A_{t^{-}} \text {return on assets; }\end{array}$ \\
\hline \multicolumn{2}{|c|}{ Ball \& Shivakumar model (2006) } \\
\hline 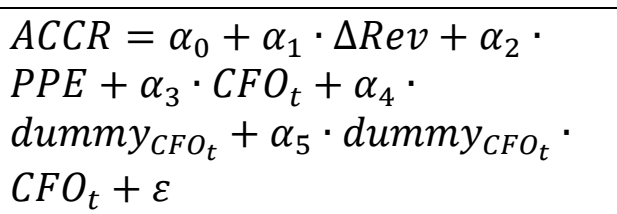 & $\begin{array}{l}A C C R-\text { total accrual; } \triangle R e v-\text { change in revenue; } P P E- \\
\text { gross value of property, plant and equipment; dummy } y_{C F O_{t}}{ }^{-} \\
\text {incidence of negative earnings realization; dummy }{ }_{C F O_{t}} \text {. } \\
\mathrm{CFO}_{t^{-}} \text {composed effect of earnings timeliness; }\end{array}$ \\
\hline
\end{tabular}

Source: adaptation after Price et. al. (2010); Dechow et. al. (2010)

When measuring earnings quality, the literature gives a wide range of models built to respond only to partial considerations of earnings quality. In table 1 we remind the most frequently used models. All these models base on some basic determinants which refer to the variance of the revenue $(\triangle R e v)$, the change in receivables $(\triangle R e c)$, the level of PPE, the level of CFO and the variation effect $(\triangle C F O)$ on the accruals level (ACCR) or on the change on accruals $(\triangle A C C R)$. Is widely admitted that these indicators reveal best the changes on a time series analysis of the financial statements figures, in order to identify probable use of earnings manipulation techniques.

The sample consist of the 31 companies with the first most liquid stock shares transacted on the Bucharest Stock Exchange, except the financial entities which are reporting under different accounting regulation. All financial information were gathered on a database by consulting each company's website and financial statements published on the BSE website. The sample consist of $86.67 \%$ companies with private capital, and $13.33 \%$ state-owned companies. Companies with foreign capital represent $23.33 \%$ from the sample. The entire sample sums $28.73 \%$ from the BSE capitalization based on July 2014 figures. Below is depicted the sample structure based on the domain of activity the entity is operating.

Sample distribution by activity

Graph 1

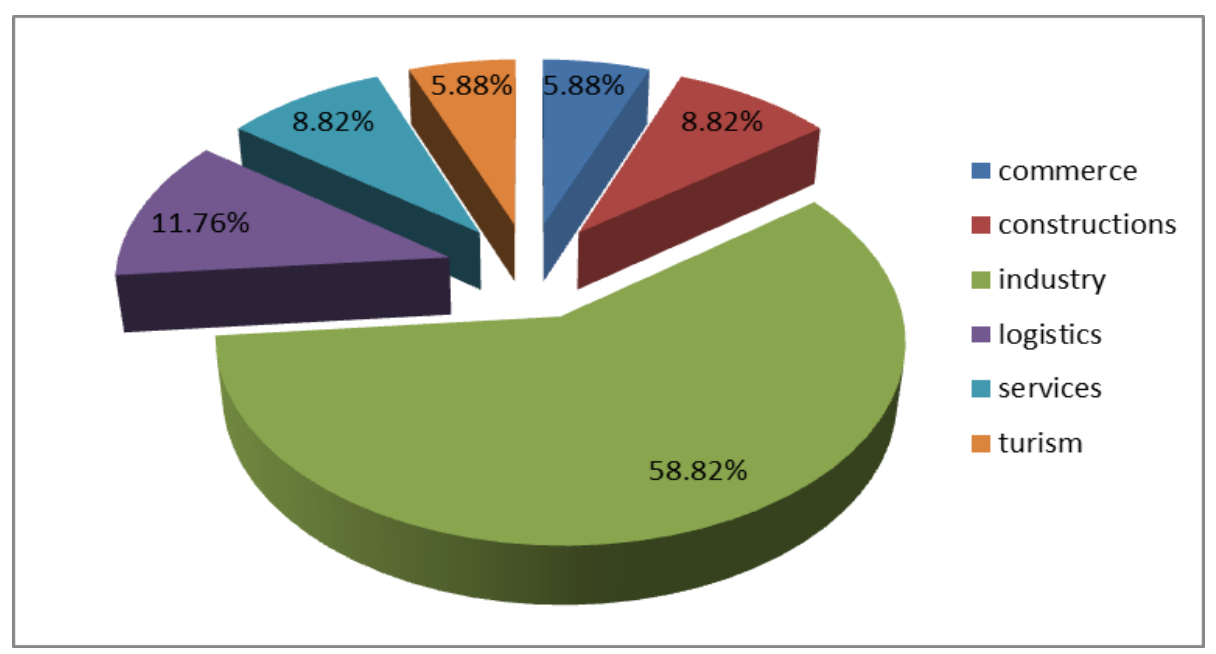

This study is designed to check the quality of accruals disclosed by a sample of listed entities, using a comparative approach between IFRS pre-adoption period and IFRS post-adoption 
time. For this we will a sample of 30 listed companies on Bucharest Stock Echange, choosing as period of analysis the financial exercises from 2009-2013. As IFRS were used beginning with 2012 financial exercise, we have compared the accounting figures referred to 2009-2011 with the ones concerning financial exercises 2011-2013. If the financial statements were prepared according to OMFP 3055/2009 on the timeframe of 2009-2011, the financial statements for 2012-2013 were prepared according to IFRS. To these observations we add the figures for financial exercise of 2011, reported in compliance with IFRS, within the reconciliation statements.

We will define earnings quality as Dechow \& Schrand (2004) did, through earnings persistence, earnings smoothing and earnings timeliness. The accruals quality is tested on a econometric approach, using Jones modified model (1995), Dechow (2002), Kothari \& Jones (2005) and Ball \& Shivakumar (2006) models. All the mentioned models are just derivates from the Jones model (1991) and Dechow model (2002). Every econometric model that will be estimated in this work is numbered in order to make the connection with the statistics of the regression model estimated.

As IFRS is based on principle-based philosophy, we expect that earnings smoothing and earnings predictability to improve after IFRS are being used on preparing the financial statements. Even though managers get the proper tools to report a fair image of the financial position and economic performance of an entity, as we discussed, they are involved in this equation also reporting incentives managers that look to maximize in their interest. This way, based on the existing evidence regarding behavioral finance, the investors look for shares will lower variation and high rate of remuneration. Additionally to the targeted lower variance, investors also pay attention to the trend a share price is following, if it is ascending or not. Anyway, any listed entity will not assume the risk to report high earnings level in good financial year if they are not sure they will keep at least the current level of the earnings in the next financial exercises, too. All these would plead for accounting treatments determining more predictable earnings with small variation on a medium and long term.

\section{$\mathrm{H}_{1}$ : Earnings predictability increase after IFRS adoption}

\section{$\mathrm{H}_{2}$ : Earnings smoothing is more visible after IFRS adoption}

\section{$\mathrm{H}_{3}$ : Earnings conditional conservatism is lower after IFRS adoption}

On the other hand, accounting conservatism is specific to continental accounting model, but this does not mean IASB accounting model is excluding the principle of accounting prudence. This topic is under discussion even after decades of discussion as it is deeply affected by the uncertainty of each transaction. If investors concentrate their attention on the profit and loss statement in order to view earnings evolution, financial institutions prefer focusing on the balance-sheet statement, in order to determine entity's solvency and liquidity as an insurance they will recover their investments. As even IASB conceptual framework is positioning the investors as main beneficiaries of the financial information, it is expected that accounting conservatism to be less present adopt IFRS adoption. The problem raise when we refer to conditional conservatism, which is a form of accounting conservatism, defined as asymmetric timeliness in the recognition of good and bad news in reported earnings. Here managers' intention is critical as it involves use of various techniques of creative accounting, as is the case of big bath accounting. Managers' decision regarding accounting choice depends on their objectives, but can be constrained by proper sanctions that enforcement actors can apply. Considering Olimid \& Calu (2006) study, which state Romanian accountants prefer statutory control and conservatism, we expect conditional conservatism will be affected, but in a lower measure. Above we have formulated the statistical hypothesis concerning earnings quality that will be checked for validation. 
To evaluate earnings conditional conservatism we will use Model 1, Model 2 and Model 3, where $E B I T_{t_{r e g}}$ represent the gross profit obtained by an entity in financial exercise $t$, with financial statements prepared according to accounting regulation reg. These models express the measure the gross profit in current year is explained by the gross profit from previous year, and the conditional conservatism characterizing accounting practices. The conditional conservatism dummy variable is coded as 0 in case the result is a profit, or -1 in case the result in a loss. This way, they are explained the timeliness of profit versus loss recognition. In case the accounting treatments are excessively prudent, there should be observed a timely recognition of losses, compared to the case of registering a profit. 


\section{Conditional conservatism econometric models}

Model 1: $E B I T_{2012_{I F R S}}=\alpha_{0}+\alpha_{1} \cdot D_{2011_{R C R}}+\alpha_{2} \cdot E B I T_{2011_{R C R}}+\alpha_{3} \cdot E B I T_{2011_{R C R}} \cdot D_{2011_{R C R}}+\varepsilon_{t}$

Model 2: $E B I T_{2012_{I F R S}}=\alpha_{0}+\alpha_{1} \cdot D_{2011_{I F R S}}+\alpha_{2} \cdot E B I T_{2011_{I F R S}}+\alpha_{3} \cdot E B I T_{2011_{I F R S}} \cdot D_{2011_{I F R S}}+\varepsilon_{t}$

Model 3: $E B I T_{2013_{I F R S}}=\alpha_{0}+\alpha_{1} \cdot D_{2012_{I F R S}}+\alpha_{2} \cdot E B I T_{2012_{I F R S}}+\alpha_{3} \cdot E B I T_{2012_{I F R S}} \cdot D_{2012_{I F R S}}+\varepsilon_{t}$.

\section{Earnings predictibility econometric models}

$$
\begin{aligned}
& \text { Model 4: } E B I T_{2010_{R C R}}=\alpha_{0}+\alpha_{1} \cdot E_{B I T_{2009} R C R}+\varepsilon_{t} \\
& \text { Model 5: } E B I T_{2011_{R C R}}=\alpha_{0}+\alpha_{1} \cdot E B I T_{2010_{R C R}}+\varepsilon_{t}
\end{aligned}
$$

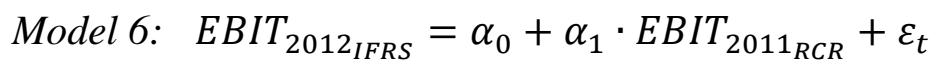

$$
\begin{aligned}
& \text { Model 7: } E B I T_{2012_{I F R S}}=\alpha_{0}+\alpha_{1} \cdot E B I T_{2011_{I F R S}}+\varepsilon_{t} \\
& \text { Model 8: } E B I T_{2013_{I F R S}}=\alpha_{0}+\alpha_{1} \cdot E B I T_{2012_{I F R S}}+\varepsilon_{t} \text {. }
\end{aligned}
$$

\section{Accruals quality econometric models ${ }^{3}$}

Model 9: $\frac{\operatorname{ACCR}_{2011_{R C R}}}{\text { Assets }_{2011_{R C R}}}=\alpha_{0}+\alpha_{1} \cdot \frac{\left(\Delta \operatorname{Rev}_{R C R_{10-11}}-\Delta \operatorname{Rec}_{R C R_{10-11}}\right)}{\operatorname{Assets}_{2011_{R C R}}}+\alpha_{2} \cdot \frac{P P E_{2011_{R C R}}}{\text { Assets }_{2011_{R C R}}}+\varepsilon_{t}$

Model 10: $\frac{\text { ACCR }_{2011_{I F R S}}}{\text { Assets }_{2011_{\text {IFRS }}}}=\alpha_{0}+\alpha_{1} \cdot \frac{\left(\Delta \operatorname{Rev}_{\text {mixt }_{10-11}}-\Delta \operatorname{Rec}_{\text {mixt }}{ }_{10-11}\right)}{\text { Assets }_{2011_{\text {IFRS }}}}+\alpha_{2} \cdot \frac{\text { PPE }_{2011_{I F R S}}}{\text { Assets }_{2011_{I F R S}}}+\varepsilon_{t}$

Model 11: $\frac{\text { ACCR }_{2012}{ }_{I F R S}}{\text { Assets }_{2012}{ }_{I F R S}}=\alpha_{0}+\alpha_{1} \cdot \frac{\left(\operatorname{SRev}_{I F R S_{11-12}}-\Delta \operatorname{Rec}_{I F R S_{11-12}}\right)}{\text { Asset }_{2012}{ }_{I F R S}}+\alpha_{2} \cdot \frac{P P E_{2012}{ }_{I F R S}}{\text { Assets }_{2012}{ }_{I F R S}}+\varepsilon_{t}$

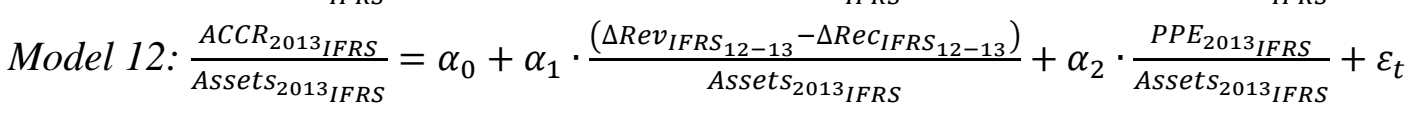

Model 13: $\frac{\triangle \text { ACC }_{09-10_{R C R}}}{\text { Assets }_{2010_{R C R}}}=\alpha_{0}+\alpha_{1} \cdot \frac{C F O_{2009_{R C R}}}{\text { Assets }_{2009_{R C R}}}+\alpha_{2} \cdot \frac{C F O_{2010_{R C R}}}{\text { Assets }_{2010_{R C R}}}+\alpha_{1} \cdot \frac{C F O_{2011_{R C R}}}{\text { Assets }_{2011_{R C R}}}+\varepsilon_{t}$

Model 14: $\frac{\Delta \text { ACC }_{10-11_{R C R}}}{\text { Assets }_{2011_{R C R}}}=\alpha_{0}+\alpha_{1} \cdot \frac{C F O_{2010_{R C R}}}{\text { Assets }_{2010_{R C R}}}+\alpha_{2} \cdot \frac{C F O_{2011_{R C R}}}{\text { Assets }_{2011_{R C R}}}+\alpha_{1} \cdot \frac{C^{2} O_{2012_{I F R S}}}{\text { Assets }_{2012_{I F R S}}}+\varepsilon_{t}$

${ }^{3}$ RCR index means accounting figures are reported under provisions of Romanian accounting regulation; IFRS index means accounting figures are reported under provisions of IFRSs;

The other notations remain the same as meaning, as used in econometric models testing earnings quality; 
Model 15: $\frac{\triangle A C C_{11-12_{I F R S}}}{\text { Assets }_{2012_{I F R S}}}=\alpha_{0}+\alpha_{1} \cdot \frac{C F O_{2011_{R C R}}}{\text { Assets }_{2011_{R C R}}}+\alpha_{2} \cdot \frac{C F O_{2012_{I F R S}}}{\text { Assets }_{2012_{I F R S}}}+\alpha_{1} \cdot \frac{C^{2} O_{2013}{ }_{2 F R S}}{\text { Assets }_{2013_{I F R S}}}+\varepsilon_{t}$

Model 16: $\frac{\triangle A C C_{11-12_{I F R S}}}{\text { Assets }_{2012_{\text {IFRS }}}}=\alpha_{0}+\alpha_{1} \cdot \frac{C F O_{2011_{\text {IFRS }}}}{\text { Assets }_{2011_{\text {IFRS }}}}+\alpha_{2} \cdot \frac{C F O_{2012_{I F R S}}}{\text { Assets }_{2012_{I F R S}}}+\alpha_{1} \cdot \frac{C F O_{2013_{I F R S}}}{\text { Assets }_{2013_{\text {IFRS }}}}+\varepsilon_{t}$

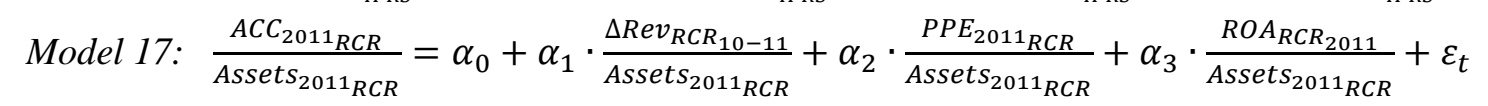

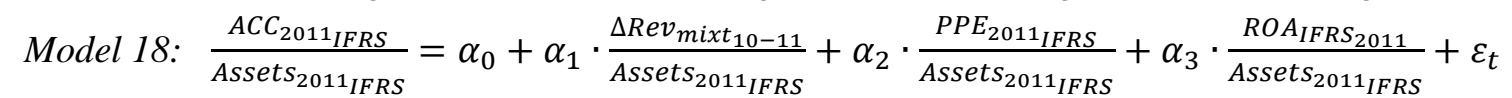

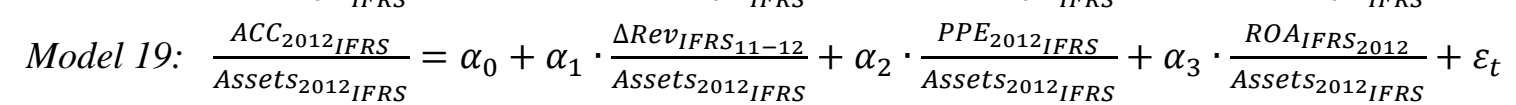

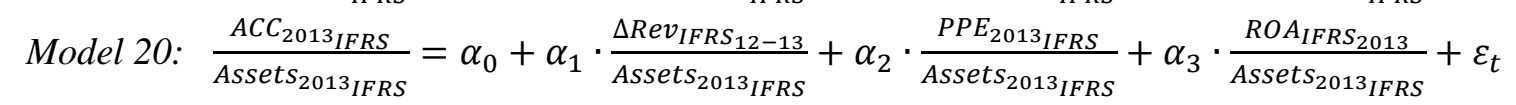

Model 21: $\frac{A C C_{2011_{R C R}}}{\text { Asset }_{2011_{R C R}}}=\alpha_{0}+\alpha_{1} \cdot \frac{\Delta \text { Rev }_{R C R_{10-11}}}{\text { Asset }_{2011_{R C R}}}+\alpha_{2} \cdot \frac{P P E_{2011_{R C R}}}{\text { Assets }_{2011_{R C R}}}+\alpha_{3} \cdot \frac{C F O_{2011_{R C R}}}{\text { Assets }_{2011_{R C R}}}+\alpha_{4} \cdot \frac{D_{C F O_{2011_{R C R}}}}{\text { Assets }_{2011_{R C R}}}+\alpha_{5} \cdot \frac{D_{C F O_{2011_{R C R}}}}{\text { Assets }_{2011_{R C R}}} \cdot \frac{C F O_{2011_{R C R}}}{\text { Assets }_{2011_{R C R}}}+\varepsilon_{t}$

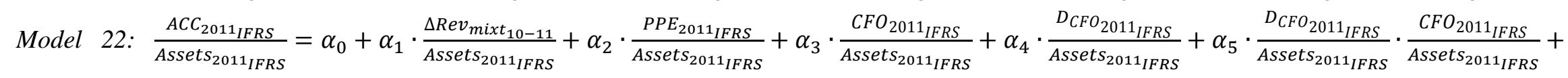
$\varepsilon_{t}$

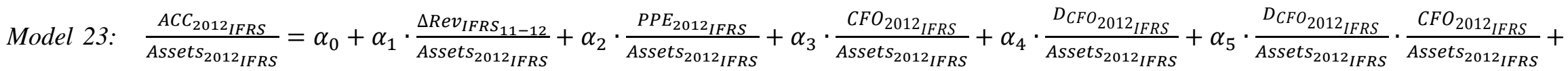
$\varepsilon_{t}$

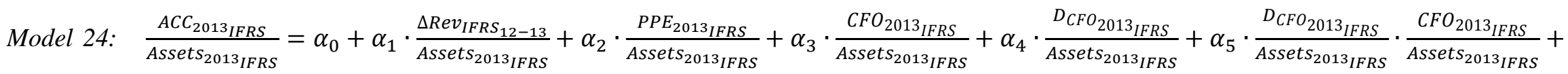
$\varepsilon_{t}$

Model 25: $\frac{A C C_{2011_{R C R}}}{\text { Assets }_{2011_{R C R}}}=\alpha_{0}+\alpha_{1} \cdot \frac{\left(\Delta \operatorname{Rev}_{R C R_{10-11}}-\Delta \operatorname{Rec}_{R C R_{10-11}}\right)}{\operatorname{Assets}_{2011_{R C R}}}+\alpha_{2} \cdot \frac{P P E_{2011_{R C R}}}{\operatorname{Assets}_{2011_{R C R}}}+\alpha_{3} \cdot \frac{\text { ROA }_{R C R_{2011}}}{\text { Assets }_{2011_{R C R}}}+\varepsilon_{t}$

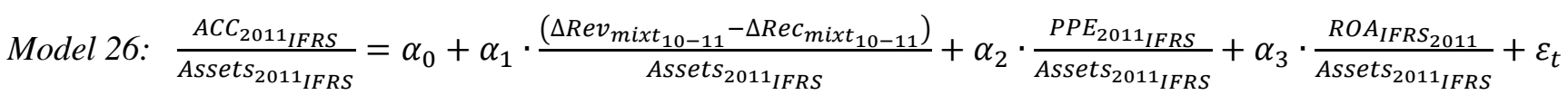

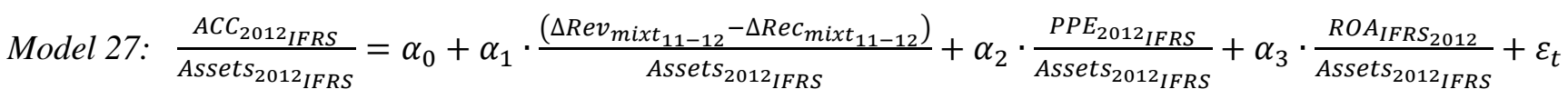

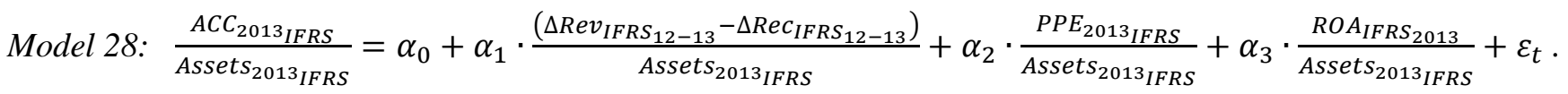


Earnings smoothing will be calculated using the relation expressing the percentage the variation of EBIT which can explain the variation of the CFO. Mathematically, this is expressed by relation $n=\frac{\sigma\left(E B I T_{t}\right)}{\sigma\left(C F O_{t}\right)}$, where $\sigma\left(E B I T_{t}\right)$ express EBIT variability in year $t$, and $\sigma\left(C F O_{t}\right)$ represent operations cash flow variability, both along the sample analyzed. As accrual accounting impact on accounting figures is desirable to be as low as possible, the value of $n$ has to be closer to 0 . This would mean that these is strong relation between the gross profit and the cash flow generated by operational activities.

The last part of the study is analyzing accruals quality, in order to see the proportion of the accruals generated by real activities versus accounting choice. All these econometric tests reflect a sensitivity analysis, from the perspective of accruals quality. For this we will compare accruals level with CFO level, in order to check the proportion of EBIT which is explained rather by accruals accounting than cash accounting. In case of capital-market based economies, importance for cash flow statement is significantly higher than in case of credit-based economies, as they are the real proof of the economic value of a company. As we will see, earnings are significantly affected by accounting treatments, deterring the predictability of the cash flows. Special focus is paid to revenue recognition, receivables variations, and level of PPE in total assets structure (because of the accounting treatment for assets depreciation). All models we are testing have something in common, namely the dynamics included in the econometric models tested $(\triangle A C C, \Delta R e v, \Delta R e c)$. This is because techniques as earnings smoothing can be detected only if we proceed to time series analysis of the accruals level, for at least 3 consecutive years.

By $\Delta R e v_{\text {mixt }}{ }_{t-(t+1)}=R e v_{I F R S_{t+1}}-\operatorname{Rev}_{R C R_{t}}$ and $\Delta R e c_{\text {mixt }} t_{t-(t+1)}=\operatorname{Rec}_{I F R S_{t+1}}-\operatorname{Rec}_{R C R_{t}}$, we mean they are mixed differences calculated between revenue $(R e v)$ and receivable $(R e c)$ figures from year $t$, reported according to Romanian accounting regulation and year $(t+1)$ reported according to IFRS. This way, we measure the impact of relative difference on the $\mathrm{R}$ squared of the econometric model. In case we see a significant variation between $\mathrm{R}$ squared for models using this type of differences and $\mathrm{R}$ squared for models using simple differences based on figures reported on the same accounting regulation, we can admit that IFRS adoption brings visible changes in accounting figures. This is the case of Model 10 which has to be compared with Model 9 and Model 11 (impact of revenue and receivables changes); Model 18 compared with Model 17 and Model 19 (impact of revenue changes); Model 22 compared with Model 21 and Model 23 (impact of revenue changes); or Model 26 compared with Model 25 and Model 27 (impact of revenue and receivables changes).

Once estimated, for all these models we will check their R squared in order to see the determinants of the accruals. Multiple regression models are most suitable, as they show information about the synergetic effect of multiple accounting-based covenants on accruals evolution. Also, these models enable us to emphasize the financial statement that explain better the accruals evolution, balance-sheet statement versus profit \& loss statement, in terms of $\mathrm{R}$ squared variation.

We will check also for the evolution of discretionary accruals within the level of total accruals, described by the residual component of the econometric models $\left(\varepsilon_{t}\right)$.

To estimate the econometric linear regression models, we will use the Eviews 7.0 software. IFRS impact is outlined by the econometric models where the variables for prior year are reported according to RAS regulation, and the variables of variance are calculated taking as initial base the financial figures reported according to IFRS requirements. 


\section{Results and discussion}

In Romanian environment there still is place for discussion regarding IFRS adoption effects on consolidated accounts and statutory accounts as well. First attempt on studying the relevance of accruals models in the Romanian economic environment is made by Matis et. al. (2010). Their study validate Jones (1991) model, rejecting the model validity in case of Dechow (2002) and Kasznik model (1999). They focused their research on the consolidated accounts, as IFRS was mandated for these financial statements from 2007, considering a sample of BSE listed companies for which they gathered firm observations for 2007 and 2008.

All financial performance indicators are affected by the reclassifications and measurement accounting policies used, as is the case of using fair value, in a transition capital market. But these figures have to be analyzed cautiously as in the transition process of IFRS implementation managers can use some exemptions provided by IFRS 1, raising considerable temporary difference between the accounts reported on the base of Romanian accounting regulation and the accounts reported under the IFRS requirements. These differences represent nothing but transitory accruals that determine KPIs improvement only for short time. They are preferred by the managers as managers' strategic perspective is shorter than the investors' one, in order to increase their yearly bonuses.

Table 3

IFRS adoption on accruals components

\begin{tabular}{|l|r|c|c|r|r|r|r|r|r|}
\hline \multirow{2}{*}{$\begin{array}{l}\text { Regulation } \\
\text { /Year }\end{array}$} & \multicolumn{3}{|c|}{ Accruals } & \multicolumn{3}{c|}{ CFO } & \multicolumn{3}{c|}{ EBIT } \\
\cline { 2 - 11 } & RAS & \multicolumn{1}{|c|}{ IFRS } & $\%$ & \multicolumn{1}{c|}{ RAS } & IFRS & $\%$ & $R A S$ & IFRS & $\%$ \\
\hline Mean & -0.017 & -0.013 & $23.99 \%$ & 0.075 & 0.056 & $-24.43 \%$ & 0.058 & 0.042 & $-26.57 \%$ \\
\hline Maximum & 0.097 & 0.101 & - & 0.236 & 0.174 & - & 0.225 & 0.137 & - \\
\hline Minimum & -0.197 & -0.198 & - & -0.085 & -0.083 & - & -0.045 & -0.117 & - \\
\hline Std. Dev. & 0.064 & 0.065 & $2.10 \%$ & 0.083 & 0.061 & $-26.93 \%$ & 0.061 & 0.054 & $-11.51 \%$ \\
\hline $\begin{array}{l}\text { Jarque- } \\
\text { Bera }\end{array}$ & 1.980 & 1.704 & - & 1.053 & 0.613 & - & 3.857 & 4.447 & - \\
\hline Probability & 0.371 & 0.427 & - & 0.591 & 0.736 & - & 0.145 & 0.108 & - \\
\hline
\end{tabular}

Source: calculation with Excel

There is clear that IFRS adoption has raised significant increase in accruals components, the impact being relatively homogenous along entire samples as the variance coefficient is of only $8.75 \%\left(\partial=\frac{2.10 \%}{23.99 \%}\right)$, meaning that whatever industry is, the managers make use of accounting choice to manipulate the financial performance. Anyway, in terms of relative figures, there is a visible correlated decrease in the means of accruals and CFO, as well, which lead us to the conclusion that earnings become more accurate in connection with cash flows. But we have to see these results closely connected with the standard variation for accruals and CFO as well.

Compared to accruals variation percentage, $\mathrm{CFO}$ variation is really high, as it is higher than $100 \%$. This means the sample is not homogenous from CFO perspective, leading us to the conclusion earnings manipulation is visible, not through accounting choice scenario, but also through real activity management. Even though, we can observe a slight decrease on CFO standard deviation from 0.083 (in case of accounts reported under Romanian accounting regulation) to a level of 0.061 (in case of accounts reported in compliance with IFRS). Compared with the standard deviation on EBIT, which is from 0.061 (in case of accounts reported under Romanian accounting regulation) to 0.054 , there is higher increase, which lead us 
to the interpretation that even if accounting manipulation is no significant because of accounting choice changes through IFRS implementation process, this phenomena exists. Further research can be done for a wider timeframe as soon as the data would be available for such a business case.

Table 9

\section{Correlation matrix RAS accounts}

\begin{tabular}{|c|c|c|c|c|c|c|c|c|c|c|}
\hline \multirow{2}{*}{\multicolumn{2}{|c|}{ Regulation/Year }} & \multicolumn{3}{|c|}{ Accruals } & \multicolumn{3}{|c|}{ CFO } & \multicolumn{3}{|c|}{ EBIT } \\
\hline & & 2009 & 2010 & 2011 & 2009 & 2010 & 2011 & 2009 & 2010 & 2011 \\
\hline \multirow{3}{*}{ Accruals } & 2009 & 1 & & & & & & & & \\
\hline & 2010 & 0.354 & 1 & & & & & & & \\
\hline & 2011 & 0.061 & 0.247 & 1 & & & & & & \\
\hline \multirow{3}{*}{ CFO } & 2009 & -0.771 & -0.184 & -0.022 & 1 & & & & & \\
\hline & 2010 & -0.492 & -0.692 & -0.120 & 0.570 & 1 & & & & \\
\hline & 2011 & -0.309 & -0.081 & -0.680 & 0.475 & 0.472 & 1 & & & \\
\hline \multirow{3}{*}{ EBIT } & 2009 & -0.029 & 0.130 & 0.037 & 0.659 & 0.315 & 0.381 & 1 & & \\
\hline & 2010 & -0.282 & 0.157 & 0.108 & 0.577 & 0.604 & 0.557 & 0.573 & 1 & \\
\hline & 2011 & -0.356 & 0.146 & 0.111 & 0.621 & 0.516 & 0.653 & 0.555 & 0.867 & 1 \\
\hline
\end{tabular}

Source: calculation with Eviews 7.0

Table 10

Correlation matrix IFRS accounts

\begin{tabular}{|c|c|c|c|c|c|c|c|c|c|c|}
\hline \multirow{2}{*}{\multicolumn{2}{|c|}{ Regulation/Year }} & \multicolumn{3}{|c|}{ Accruals } & \multicolumn{3}{|l|}{ CFO } & \multicolumn{3}{|l|}{ EBIT } \\
\hline & & 2011 & 2012 & 2013 & 2011 & 2012 & 2013 & 2011 & 2012 & 2013 \\
\hline \multirow{3}{*}{ Accruals } & 2011 & 1 & & & & & & & & \\
\hline & 2012 & 0.661 & 1 & & & & & & & \\
\hline & 2013 & 0.174 & 0.029 & 1 & & & & & & \\
\hline \multirow{3}{*}{ CFO } & 2011 & -0.635 & -0.232 & -0.059 & 1 & & & & & \\
\hline & 2012 & -0.155 & -0.499 & -0.005 & 0.469 & 1 & & & & \\
\hline & 2013 & 0.130 & 0.360 & -0.696 & 0.259 & 0.247 & 1 & & & \\
\hline \multirow{3}{*}{ EBIT } & 2011 & 0.476 & 0.527 & 0.159 & 0.371 & 0.338 & 0.435 & 1 & & \\
\hline & 2012 & 0.603 & 0.691 & 0.027 & 0.134 & 0.281 & 0.605 & 0.866 & 1 & \\
\hline & 2013 & 0.375 & 0.526 & 0.172 & 0.290 & 0.333 & 0.588 & 0.776 & 0.861 & 1 \\
\hline
\end{tabular}

Source: calculation with Eviews 7.0

In case of accounts reported under Romanian accounting regulation, the correlations are altered over time, as the accounting estimate and professionals judgment explain major part of the firm's financial performances. But there must be paid attention to the fact that such approach may deter over time the comparability of financial information with implications on investment decision and firm valuation. 
Earnings timeliness

\begin{tabular}{|c|c|c|c|c|c|c|}
\hline Regulation & Year & $\begin{array}{c}\text { Model } \\
\text { Number }\end{array}$ & $\begin{array}{l}\text { Adjusted } \\
\qquad \mathbf{R}^{2}\end{array}$ & F stat & Sig. F & $\begin{array}{c}\text { Durbin- } \\
\text { Watson } \\
\text { stat }\end{array}$ \\
\hline \multirow{3}{*}{ IFRS } & $\begin{array}{c}2012 \\
\text { RAS }\end{array}$ & Model 1 & $9.69 \%$ & 2.072 & $12.74 \%$ & 1.846 \\
\hline & 2012 & Model 2 & $87.49 \%$ & 70.910 & $0.000 \%$ & 2.134 \\
\hline & 2013 & Model 3 & $58.33 \%$ & 14.996 & $0.001 \%$ & 1.976 \\
\hline
\end{tabular}

Source: calculation with Eviews 7.0

In case of IFRS accounts, correlation matrix describe the highest correlation between accruals versus CFO and a accruals versus EBIT in 2012, and lower correlation in 2011 and 2013. This can be interpreted as potential use of big bath accounting, as the accounts from 2012 were disclosed same time with accounting with the accounts corresponding to 2011 reconciled financial year. Companies prefer to disclose higher losses in the financial years affected by IFRS implementation, justifying the bad results by referring to accounting changes generated by transition to IFRS.

Unfortunately, the result in Table 4 suggests a persistence of the accounting conditional conservatism in the managers accounting policies, widely explained by the cultural factor and considerations regarding tax burden. But there is evidence that IFRS has determined the financial information to be less conservative (the $\mathrm{R}^{2}$ has increased from $9.69 \%$ to $87.49 \%$ in 2012). These results can be either explained, by the accruals level that we already mentioned have increased once the IFRS were used for statutory financial statements preparation.

Earnings smoothing

Table 5

\begin{tabular}{|l|c|r|r|c|}
\hline Regulation & Year & $\Delta$ Earnings & $\Delta$ CFO & \% \\
\hline RAS & 2009 & 0.039 & 0.061 & 0.637 \\
\hline & 2010 & 0.057 & 0.078 & 0.731 \\
\hline & 2011 & 0.061 & 0.083 & 0.737 \\
\hline IFRS & 2011 & 0.054 & 0.061 & 0.893 \\
\hline & 2012 & 0.069 & 0.058 & 1.199 \\
\hline & 2013 & 0.066 & 0.090 & 0.729 \\
\hline
\end{tabular}

Source: calculation with Eviews 7.0

Overall, regarding earnings smoothing, the results from Table 5 suggest the flexibility of the new principle-based financial reporting framework, as the relation between earnings variation and CFO variation seem to be much closer to the unit value. The outlier of 1.199 could be explained by the fact that figures referring to 2012 financial year are deeply affected by a set of reclassification of expenses in assets, and the problem of using different valuation base once IFRS are adopted. 
Earnings persistence

\begin{tabular}{|c|c|c|c|c|c|c|}
\hline Regulation & Year & $\begin{array}{c}\text { Model } \\
\text { Number }\end{array}$ & $\begin{array}{c}\text { Adjusted } \\
\mathbf{R}^{\mathbf{2}}\end{array}$ & F stat & Sig. F & $\begin{array}{c}\text { Durbin- } \\
\text { Watson } \\
\text { stat }\end{array}$ \\
\hline RAS & 2010 & Model 4 & $30.57 \%$ & 14.206 & $0.075 \%$ & 1.809 \\
\hline & 2011 & Model 5 & $74.29 \%$ & 87.698 & $0.000 \%$ & 2.195 \\
\hline IFRS & $2011_{\text {RAS }}$ & Model 6 & $54.67 \%$ & 36.183 & $0.000 \%$ & 2.111 \\
\hline & 2012 & Model 7 & $74.15 \%$ & 87.044 & $0.000 \%$ & 2.201 \\
\hline & 2013 & Model 8 & $73.15 \%$ & 82.739 & $0.000 \%$ & 2.867 \\
\hline
\end{tabular}

Source: calculation with Eviews 7.0

Even though, the results must be interpreted carefully, because we can see that on 2013 financial year the fraction between the variation of earnings and CFO has decreased again. This can be directly correlated with Daske et. al. (2013) results, who's study revealed higher positive results once IFRS is adopted especially in the first years of adoption, with a slight decrease in the following years. This means that there is necessary a wider time frame to analyze earnings evolution, in order to make difference between the entities adopting sincerely IFRS and entities using this opportunity just to change accounting treatments in order to reduce the tax burden, or obtain short-term share-price increase in case they are listed.

In Table 6, the results have to be analyzed in correlation with the results from Table 4. They outline the fact that, indeed there is significant conditional conservatism in managers financial reporting strategies, especially in case of figures obtained in compliance with Romanian accounting regulation. It is the case of the regression model reflected in Model 1 versus Model 4, where the difference would be of approximately $21.08 \%$ ( calculated as R squared from Model 1, namely 30.57\%, deducted by the R squared for Model 4, namely 9.69\%). This would be impact on $\mathrm{R}$ squared of integrating the variable reflecting asymmetric timeliness of loss recognition. In case of figures reported under IFRS requirements the situation has improved significantly, but still persist as the value of $\mathrm{R}$ squared describing Model 3 state a lower value of $58.33 \%$, compared to the value of R squared in case of Model 8 is of $73.15 \%$.

Following part of the study is analyzing this time the quality of the financial information from the perspective of the accruals quality evolution drawn once IFRS were adopted on preparing the statutory financial statements. From Graph 2 there is clear evidence that Jones modified model (1995) and Kothari \& Jones (2005) models are not valid for Romanian economic environment as for 2012 financial year the regression models estimated are really low, less than the significance level of $5 \%$. On these conditions, we will continue on analyzing the quality of accruals based on the Dechow (2002) and Ball \& Shivakumar (2006) models. 


\section{Adjusted R square for models tested}

Graph 2

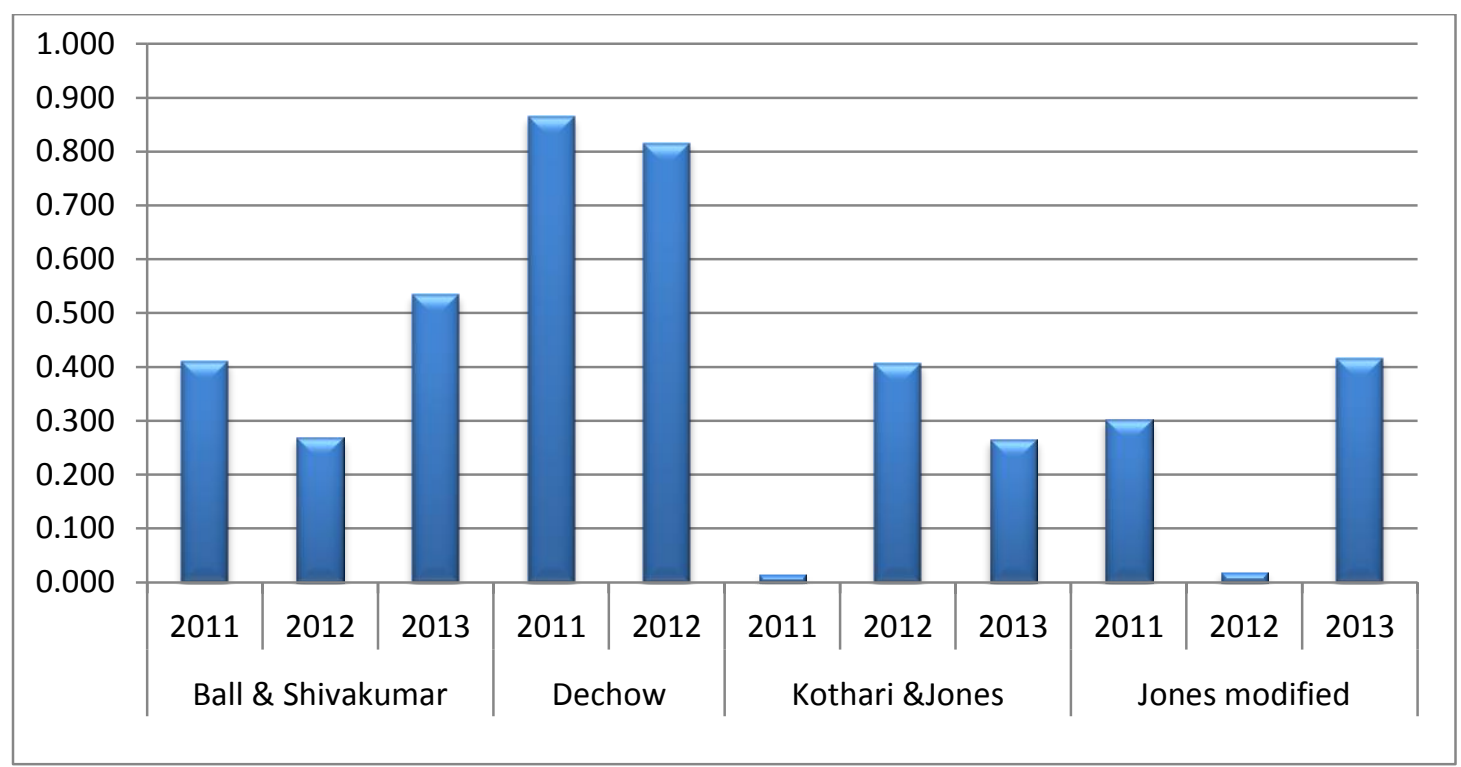


Table 7

Accruals quality testing

\begin{tabular}{|c|c|c|c|c|c|c|c|c|}
\hline \multirow[b]{2}{*}{ Model } & \multirow[b]{2}{*}{$\begin{array}{c}\text { Model } \\
\text { Number }\end{array}$} & \multirow[b]{2}{*}{ Regulation } & \multirow[b]{2}{*}{ Year } & \multicolumn{5}{|c|}{ Model overview statistics } \\
\hline & & & & $\begin{array}{c}\text { Adjusted } \\
R^{2}\end{array}$ & $\begin{array}{c}\text { S.E. of } \\
\text { regression }\end{array}$ & F stat & Sig. F & $\begin{array}{c}\text { Durbin- } \\
\text { Watson stat }\end{array}$ \\
\hline \multirow[t]{4}{*}{ Kasznik (1999) } & Model 9 & RAS & 2011 & $30.29 \%$ & 0.053 & 5.34 & $0.51 \%$ & 1.891 \\
\hline & Model 10 & IFRS & $2011_{\text {RAS }}$ & $34.84 \%$ & 0.052 & 6.35 & $0.21 \%$ & 2.208 \\
\hline & Model 11 & & 2012 & $1.90 \%$ & 0.076 & 1.19 & $33.10 \%$ & 1.653 \\
\hline & Model 12 & & 2013 & $41.64 \%$ & 0.057 & 8.14 & $0.05 \%$ & 2.274 \\
\hline \multirow[t]{4}{*}{ Dechow (2002) } & Model 13 & RAS & 2010 & $56.02 \%$ & 0.042 & 13.74 & $0.00 \%$ & 2.278 \\
\hline & Model 14 & & $2011_{\text {IFRS }}$ & $86.51 \%$ & 0.028 & 65.11 & $0.00 \%$ & 2.304 \\
\hline & Model 15 & IFRS & $2012_{\text {RAS }}$ & $78.92 \%$ & 0.035 & 38.45 & $0.00 \%$ & 2.349 \\
\hline & Model 16 & & 2012 & $81.58 \%$ & 0.025 & 45.29 & $0.00 \%$ & 1.584 \\
\hline \multirow[t]{4}{*}{ Kothari \&Jones (2005) } & Model 17 & RAS & 2011 & $1.40 \%$ & 0.067 & 0.13 & $94.30 \%$ & 2.291 \\
\hline & Model 18 & IFRS & $2011_{\text {RAS }}$ & $3.67 \%$ & 0.064 & 1.38 & $26.97 \%$ & 2.171 \\
\hline & Model 19 & & 2012 & $40.55 \%$ & 0.059 & 7.82 & $0.07 \%$ & 1.561 \\
\hline & Model 20 & & 2013 & $26.49 \%$ & 0.064 & 4.60 & $1.00 \%$ & 2.185 \\
\hline \multirow[t]{4}{*}{ Ball \& Shivakumar (2006) } & Model 21 & RAS & 2011 & $40.96 \%$ & 0.049 & 5.16 & $0.22 \%$ & 2.690 \\
\hline & Model 22 & IFRS & $2011_{\text {RAS }}$ & $29.33 \%$ & 0.055 & 3.49 & $1.57 \%$ & 2.213 \\
\hline & Model 23 & & 2012 & $26.87 \%$ & 0.066 & 3.20 & $2.27 \%$ & 2.008 \\
\hline & Model 24 & & 2013 & $53.41 \%$ & 0.051 & 7.88 & $0.01 \%$ & 2.303 \\
\hline \multirow[t]{4}{*}{ Kothari \&Jones (2005) modified } & Model 25 & RAS & 2011 & $1.03 \%$ & 0.067 & 0.09 & $96.29 \%$ & 2.333 \\
\hline & Model 26 & IFRS & $2011_{\text {RAS }}$ & $0.80 \%$ & 0.068 & 0.07 & $97.44 \%$ & 1.993 \\
\hline & Model 27 & & 2012 & $6.77 \%$ & 0.078 & 0.65 & $58.74 \%$ & 1.537 \\
\hline & Model 28 & & 2013 & $24.67 \%$ & 0.068 & 2.95 & $5.07 \%$ & 1.929 \\
\hline
\end{tabular}

Source: calculation with Eview 7.0 
In case of Dechow (2002) model we can see an increasing value of $\mathrm{R}$ squared from a value of $56.02 \%$ based on 2010 financial year figures, to value of $81.58 \%$ reflecting 2013 financial year figures, all models being statistically significant ( $\mathrm{F}$ test run states a probability of accepting the validity of the model less than 5\%). This means that the level of accruals tend to be explained better by the cash flows from operations. This conclusion is in line with results from Tabel 5, where there was underlined more correlated accruals with $\mathrm{CFO}$ values.

These results are contradictory with Matis et. al. (2010), who's study rejected the validity of Dechow model estimated on figures reported on consolidated financial statements. Within the main reasons of this contradiction we can remind the sample composition and the financial data used, as we use in our study figures disclosed on individual financial statements. Their study validate only Jones model that we do not use in our study. The difference between Jones modified model and Jones model is the integration of receivables variation which is deducted from the revenue variation, which was generated in case of some entities because of receivables reclassification.

In case of Ball \& Shivakumar model there isn't a clear trend for the correlation between accruals and CFO. The model tries to depict the existence of conditional conservatism as well, like in case of econometric models proposed for conditional conservatism measured in case of earnings. But this time, there was used the value of CFO, instead of the value of EBIT. The model describe a relative increase of the relation between accruals and CFO, but only increase of 2011 and 2013 financial year figures. 2012 financial year seem to be deeply affected, but we consider these modifications are most probably generated by some real activity accounts manipulations, affecting directly the $\mathrm{CFO}$, like is the case of managing the operational lease activities.

Graph 3

Discretionary accruals (S.E. residual component)

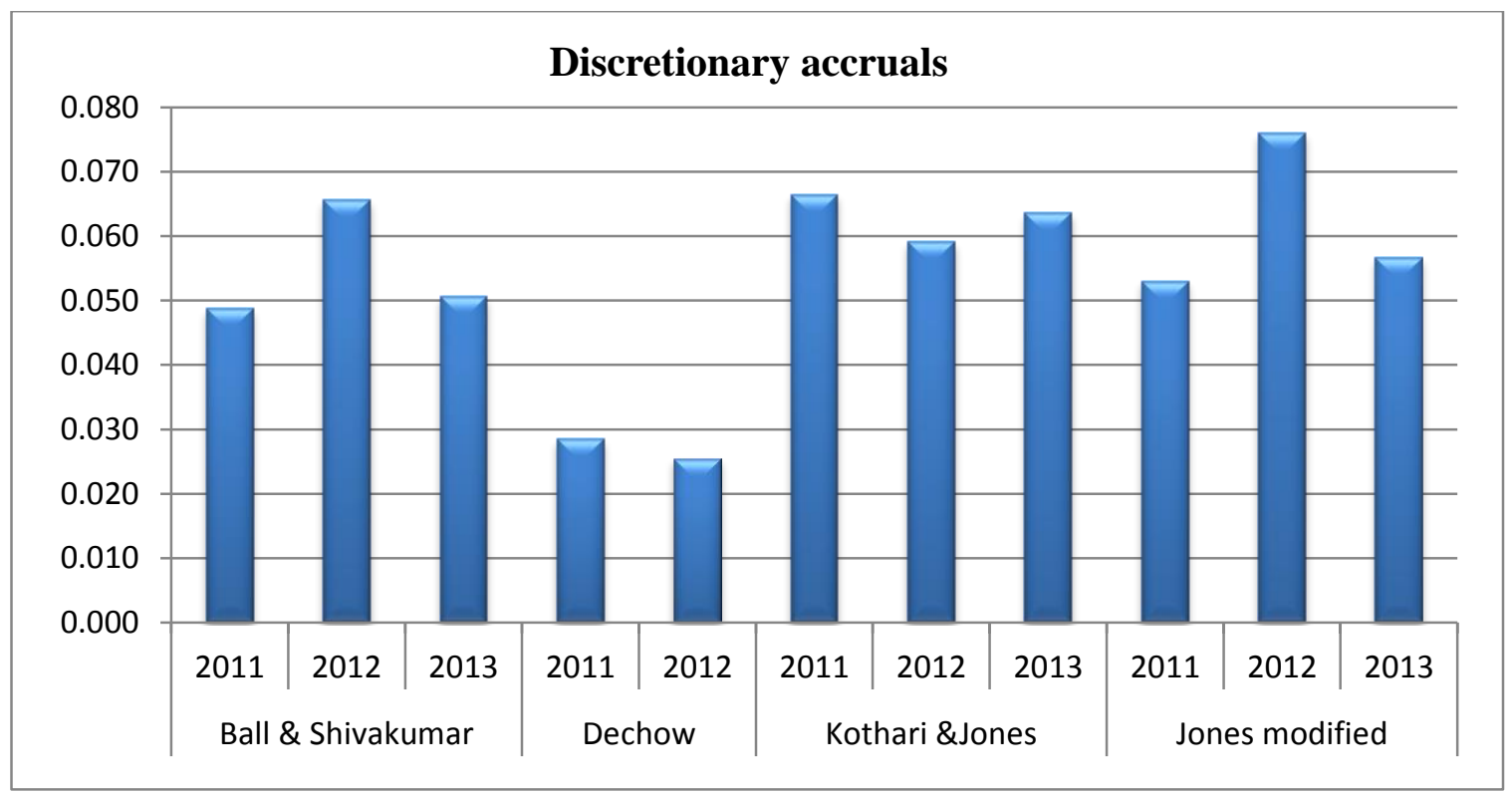

Every remark made on econometric models estimated above are confirmed by the discretionary accruals, defined in this study as the standard deviation of the accruals. It is obvious the highest values are encountered in case of 2012 financial year, namely the first time 
IFRS were adopted on preparing the statutory financial statements. As these accruals are transitory, it is essential that user of financial information to eliminate them from earnings value, in order to obtain values consistent with a long-term financial analysis perspective. These accruals are possible to be constituted as an effect of the fair value model implementation, especially in the case of the firms with a higher rate of financial instruments in total assets composition. This is justified as even IFRS 9 ,Financial instruments” has suffered lot of changes over the last years, being issued as a complete standard only this year.

Exception makes the Dechow (2002) model as it is based especially on cash accounting measures. This model confirm again the higher value relevance of cash accounting measures disclosed by financial statements, rather than the accrual accounting measures. Towards solving this problem there is opportune that prepares to start using more often economic value added measures such as residual income (RI), economic value added (EVA), cash flow return on investment (CFROI) and leave the traditional accounting measures still prescribed by Romanian accounting regulation. These measures seem to be more correlated with cash flows, and consequently with stock prices, because of the accounting adjustment made to the financial performance used, in order to eliminate accounting choice effect (Biddle et. al., 1999; Fernandez, 2002).

\section{Conclusion}

Quality of the financial reporting is essential on drawing optimal investment strategies, in order to increase shareholders value. The asymmetry between managers, shareholders and stakeholders as well, generally, lead to negative market driven effects on firm value, cost of capital and firm liquidity. As a necessity, there were conducted studies that confirmed IFRSs achieved to enhance significantly the quality. Thus, the reluctance towards IFRS adoption was visibly reduced and nowadays we are witnesses to the trend that IFRS are implemented in an increasing number of jurisdictions, not only regarding consolidated financial statements, but also on statutory financial statements.

Romanian is a similar case, as from 2012 financial exercise firms are mandated to extend IFRS use to statutory financial statements, too. There is still short debate around the costs and benefits of IFRS adoption, but they describe a more positive perception of firms towards an effective IFRS implementation.

This study reveals, also, that there is evidence for a slight increase of earnings quality. Even if the more flexible IFRS requirements permit various earnings smoothing techniques, earnings persistence and variability have improved in the first years after IFRS adoption. Dechow (2002) model seem to be the best fit to Romanian environment to describe earnings quality, as it is based especially on cash accounting measures, not affected by accounting choice.

Still, there must be paid attention to the transitory accruals generated by IFRS transition process, meaning that our research has to be continued towards enlarging the timeframe study and the sample volume. We must not forget that traditional estimation approaches of accrual models are firm-specific or industry-based and built on the implicit assumption of homogeneity of the accrual generating processes (Di Narzo et. al., 2011). But our sample is characterized by a relatively high heterogeneity of the sample, especially in the post IFRS adoption timeframe.

The results of our study must be analyzed cautiously as it difficult to make a separation between real activities earnings management and accruals management. They show a lower impact of managers accounting choice on the financial ratios. 
Within study caveats we mention the short time frame, especially on the circumstance or some changes in accounting measurement bases, or assets reclassification. These caveats can be some of the basic determinants for the discretionary accruals observed in our study. Secondly, there must be drawn attention on the fact that all the econometric models used in the study were not designed starting from Romanian economic environment, but they have the characteristic of describing in the literature cross-country samples. Third caveat would be the use of accruals generated from operating activities, rather than a global level, which will exclude the financing and investing policies impact on accounting information quality.

For future research, there is opportune a comparative analysis around earnings quality topic disclosed by publicly traded firms and private firms. Local standard-setters and institutional enforcement organisms should express a large interest on an IFRS extension to large firms which are not considered of public interest, as well. This way, national accounting practices harmonization will increase and lead to more comparable financial information on the entire financial supply chain.

\section{References}

1. Albu N., Albu C.N. (2012), International Financial Reporting Standards in an Emerging Economy: Lessons from Romania, Australian Accounting Review, vol. 22, issue 4;

2. Andre P., Filip A., Paugam L. (2013), Impact of Mandatory IFRS Adoption on Conditional Conservatism in Europe, working paper, ESSEC Business School, available on www.ssrn.com;

3. Armstrong C.S., Blouin J.L., Larcker D.F. (2012), The Incentives for Tax Planning, Journal of Accounting and Economics, vol. 53, issues 1-2;

4. Ball R., Li X., Shivakumar L. (2013), Contractibility of Financial Satement Information Prepared Under IFRS: Evidence from Debt Contracts, working paper, available on www.ssrn.com;

5. Barth M.E., Landsman W.R., Lang M., Williams C. (2012), Are IFRS-based and US GAAP-based accounting amounts comparable, Journal of Accounting and Economics, vol. 54, issue 1;

6. Barth M.E., Israeli D. (2013), Disentangling Mandatory IFRS Reporting and Changes in Enforcement, Journal of Accounting and Economics, vol. 56, issues 2-3;

7. Biddle G.C., Hillary G., Verdi R.S. (2009), How does financial reporting quality relate to investment efficiency, Journal of Accounting and Economics, wol. 43, issues 2-3;

8. Biddle G.C., Bowen R.M., Wallace J.S. (1999), Evidence on EVA, Journal of Applied Corporate Finance, vol. 12, issue 2;

9. Brad L., Dobre F., Turlea C., Brasoveanu I.V. (2014), The impact of IFRS adoption in Romania, upon the earnings management of the Bucharest Stock Exchange entities, Procedia Economics and Finance, vol. 15;

10. Burca V., Nagy M. (2013), Impact of IFRS transition on firm-valuation, an accruals analysis on BSE companies, The Young Economists Journal, issue 21; 
11. Capkun V., Hammeri A., Weiss L. (2009), Does Adoption of IAS/IFRS Deter Earnings Management, working paper, available on http://hal-hec.archives-ouvertes.fr/hal00675047

12. Chen H., Tang Q., Jiang Y., Lin Z. (2010), The Role of International Financial Reporting Standards in Accounting Quality: Evidence from the European Union, Journal of International Financial Management \& Accounting, VOL. 1, issue 3;

13. Christensen H.B., Lee E., Walker M., Zeng C. (2007), Incentives or Standards: What Determines Accounting Quality Changes Around IFRS Adoption, working paper, available on www.ssrn.com;

14. Daske H., Hail L., Laux C., Verdi R. (2013), Adopting a Label: Heterogeneity in the Economic Consequences Around IAS/IFRS Adoptions, Journal of Accounting Research, vol. 51, issue 3;

15. Dechow P. M., Schrand C.M. (2004), Earnings Quality, The Research Foundation of CFA Institute, US;

16. Dechow P.M., Ge W., Schrand C. (2010), Understanding earnings quality: A review od the proxies, their determinants and their consequences, Journal of Accounting and Economics, vol. 50, issues 2-3;

17. Demirkan S., Radhakrisham S., Urcan O. (2012) Discretionary Accruals Quality, Cost of Capital, and Diversification, Journal of Accounting, Auditing and Finance, vol. 27, issue 4

18. Demirkan S., Radhakrisham S., Urcan O. (2012) Discretionary Accruals Quality, Cost of Capital, and Diversification, Journal of Accounting, Auditing and Finance, vol. 27, issue 4

19. Di Narzo A.F., Freo M., Mattei M.M. (2011), Improving the Power of Accrual Models in Europe: The Mixture Approach, available on http://www.unibz.it/en/economics/welcome/EventsOverview.html?NewsID=51901;

20. Dichev I. D., Graham J.R., Harvey C.R., Rajgpol S. (2013), Earnings quality: Evidence from the field, Journal of Accounting and Economics, vol. 56, issue 2-3, supplement 1;

21. Feleaga N. (1999), Comparative accounting systems, vol. 1, Printing House Economica, Bucharest;

22. Fernandez P. (2002), Valuation Methods and Shareholder Value Creation, Academic Press;

23. Filip A., Raffournier B. (2010), The value relevance of earnings in a transition economy: The case of Romania, The International Journal of Accounting, vol. 45;

24. Francis J., Huang A.H., Rajgopal S., Zang A.Y. (2008), CEO Reputation and Earnings Quality, Contemporary Accounting Research, vol. 25, issue 1;

25. Graham J. R., Harvey C., Rajgopal S. (2005), The economic implications of corporate financial reporting, Journal of Accounting and Economics, vol. 40, issues 1-3;

26. Gebhardt G., Mora A., Wagenhofer A. (2014), Revisiting the fundamental concepts of IFRS, ABACUS Journal, vol. 50, issue 1; 
27. Horton J., Serafeim G., Serafeim I. (2013), Does Mandatory IFRS Adoption Improve the Information Environment, Contemporary Accounting Research, vol. 30, issue 1;

28. Ionascu M., Ionascu I., Sacarin M. (2014), IFRS adoption in developing countries: the case of Romania, Accounting and Management Information Systems, vol. 13, issue 2;

29. Ionascu M. (2011), Properties of analysts' forecasts for Romanian listed companies: how much do firm-specific factors matter?, Accounting and Management Information Systems, vol. 10, issue 3;

30. Jayaraman S., Verdi R.S. (2014), Are Reporting Incentives and Accounting Standards Substitutes or Complements in Achieving Accounting Comparability, working paper, available on www.ssrn.com;

31. Matis D., Vladu A.B., Negrea L., Sucala L. (2010), Jones, Dechow and Kasznik Models Significance In The Romanian Economic Environment, Annales Universitatis Apulensis Series Oeconomica, vol. 1, issue 12;

32. Mihai S. (2008), The impact of international accounting standards on the efficiency of the Romanian accounting reporting model, study included on The internationalization of accounting : evolutions and consequences in the Romanian environment, ASE Publishing House, Bucharest;

33. Nobes C., Stadler C. (2014), The qualitative characteristics of financial information and managers' accounting decisions: evidence from IFRS policy changes, working paper, IASB Research Forum;

34. Nobes C. (2011), International Variations in IFRS Adoption and Practice, research report 124, ACCA;

35. Olimid L., Calu D.A.St. (2006), An Empirical Study of the Accounting Values Shared By Romanian Accountants Aiming to Become Private Practitioners, working paper, available on www.ssrn.com;

36. Pascan I.D (2014), Measuring the effects of IFRS adoption in Romania on the value relevance of accounting data, Annales Universitatis Apulensis Series Oeconomica, vol. 16 , issue 2;

37. Price R.A., Sharp N.Y., Wood D.A. (2011), Detecting and Predicting Accounting Irregularities: A Comparison of Commercial and Academic Risk Measures, Accounting Horizons, vol. 25, issue 4;

38. Price R.A., Sharp N.Y., Wood D.A. (2011), Detecting and Predicting Accounting Irregularities: A Comparison of Commercial and Academic Risk Measures, Accounting Horizons, vol. 25, issue 4;

39. Ristea M., Dumitru C.G. (2012), Liberty and compliance in standards and accounting regulation, CECCAR, Bucharest;

40. Takacs L.M. (2012), The value relevance of earnings in a transition economy: evidence from Romanian stock market, Annals Universitatis Apulensis Series Oeconomica, vol. 14 , issue 1. 